\title{
SETTINGS OF INNATE AND JOINT ASSETS IN DIVORCE CASE BY LAW NUMBER 1 OF 1974 OFMARRIAGE IN THE IMPLICATIONS OF RELIGIOUS COURTS DECISION CLASS IA OF BENGKULU CITY NUMBER: 0289/PDT.G/2016/PA.BN
}

By:

Widya Eka Putri, Akhmad Muslih, Adi Bastian Salam

\begin{abstract}
Marriageraisesrights and obligations to husband and wife. The rights and obligations existing before the divorce are created from their marriage ceremony. The rights and obligations are contained in the provisions of Qur'an. To avoid conflict divorce is not an easy thing, it is motivated by several factors that cause a domestic relations be cracked even ended in divorce. The purpose of this research is to understand and analyze the factors that hinder the provision of livelihood to the former wife in divorce cases through decision of Manna Religious Court of South Bengkulu. Analyzing theproblems in this study, researchers used a analysis descriptive method to produce the research results showingfactors that inhibit the provision of livelihood to the former wife in divorce cases through decision of Manna Religious Court of South Bengkulu consisted of internal and external factors.
\end{abstract}

Keywords: Livelihood,Former Wife, divorce. 


\section{A. INTRODUCTION}

\section{Background of Research}

According to IbnuHajar quoted from Shaykh Muhammad Ash-Sharif, marriage in terms of the language is to collect and each run. ${ }^{1}$ As for the terminology of Shari'a, marriage is a contract. According to SirmanDahwal, marriage is a sacred thing, marriage is one of the religious orders. A marriage has a purpose, where the purpose of the marriage is to get a descent, creating a happy, prosperous, safe and peaceful, lovinghousehold. ${ }^{2}$

Lawful marriage will lead to legal consequences as follows: ${ }^{3}$

${ }^{1}$ Syaik Muhammad Asy-Syarif, 40 HaditsWanita,

HaditsFikihdanAkhlak,UmmulQura, 2013.pg. 1

${ }^{2}$ SirmanDahwal,

HukumPerkawinan Beda Agama DalamTeori Dan Praktiknya Di Indonesia,MandarMaju, Bandung, 2016, pg.87.

Indonesia,

${ }^{3}$ Mulyadi, HukumPerkawinan

BadanPenerbitUniversitasDiponegoro

Semarang, 2008, pg. 41.
1. The emergence of the relationship between husband and wife;

2. The emergence of asset in marriage; and

3. The emergence of relationship between parent and child.

Asset in a marriage is the right of the wife and the husband, where such property is acquired after marriage, while assets outside of marriage is an innate asset owned by husband and wife. The emergence of asset can be a temptation even for a family enjoyment, but the assetoften causes conflict. To resolve the conflict, divorcement becomes solution to solve the problem. Divorce between a husband and wife set out in Article 39 verse (1) of Law No. 1 of 1974 on Marriage states that:

"Divorce can only be done at the trial court after the relevant court 
and unsuccessfully tried to reconcile the two sides."

Divorce through talaq divorce or contested divorce can emerge legal consequences. One of them is against joint asset in marriage. Assets in marriage by Marriage Law include: ${ }^{4}$

1. Asset acquired during the marriage took place, referred to as joint assets;

2. Assetinherited from each husband and wife;

3. Assetobtained each as a gift or inheritance.

Innate assets referred in Article 36 of Law on marriage is a treasure that is rightfully fully respectively

\footnotetext{
${ }^{4}$ Mohamad Ali Afif, LiliekIstiqomah, Moh. Ali, EksekusiPutusanPengadilan Agama TerhadapHartaBersamaAkibatPercera ian(KajianPutusanPengadilan Agama PasuruanNomor 1644/Pdt.G/2011/PA. Pas, E-JurnalFakultasHukum, UniversitasJember(UNEJ),http://reposit ory.unej.ac.id/bitstream/handle/123456 789/58698/Mohamad\%20Ali\%20Afif. pdf;sequence=1, pg. 2
}

prior to the marriage or assets obtained by each party during the marriage which is not a joint venture, for example, received an inheritance, grants, gifts, and so forth.

Wealth bySoemiyatiin a marriage can be classified into three groups: ${ }^{5}$

1. Asset of each husband and wife who have been owned before married either from inherited or acquired of the other, is called innate asset;

2. Asset of each husband and wife acquired while in a marriage, not from the efforts they are acquired jointly but individually, it is required as a gift, inheritance or testament to each of them;

3. Asset acquired once they are in a marital relationship for their efforts together or one of them called a living asset. 
The emergence of innate and joint assets often lead to new conflicts in the process of divorce, in which the property can only be shared in front of the court and decided by a judge. The conflicts often arisenare a result of an imbalance in the rights and obligations of the husband and wife and that both of them want to have a large portion of the assets. One example of the conflict between innate and joint assets is Religion Court decision of Bengkulu with the case number: 0289/PDT.G/2016/PA.BN. In such case, the husband filed for divorce in Religion Court of Bengkulu, where one of the content demands was asking judges to divide the innate assets in the form of park and land fairly to him as Plaintiffand to wife as the Defendant, in addition the Plaintiff also asked the judge to decide that a motorcycle and his several hectares of garden are treasure inherited owned before marriage. It is stated in the plaintiff's claims and answers submitted in the trial. In addition to the demands of the husband as the plaintiff, the wife filed reconciliationthat the content is almost the same on the innate and joint assets. In its decision the panel of judges did not give a decision on the joint assets and in the reconciliation the panel of judges ordered the wife as the Defendant in the case and the Paintiff in reconciliation to return a motorcycle which was the husband's inheritance before marriage.

Decision of the judges with the case number: 0289/PDT.G/2016/PA.BN is a form of the role of judges as the competent authority in deciding a divorce as stipulated in the law. But the verdict is given by the judges sometimes can be judged fairly by one of the parties but unfairly by the other 
party. Therefore it needs to be seen through study of legislation and the principles of Islamic Law, one of the principle is justice.

Based on the explanation above the researcher is interested in looking at the role of judges in deciding the innate and joint assets in divorce cases reviewedfromthe principles of justice and rose it into a single entity in the form of a thesis with the title"Setting of Innate and Joint Assets Case of Divorce According to Law No. 11974 about Marriage in the Implications of Religious Court Class IaDecision of Bengkulu City Number: 0289/Pdt.G/2016/Pa.Bn."

\section{Identification of problems}

The formulation of the issues raised in this paper is: how is the innate and joint assets in divorce cases according to Law No. 11974 about Marriage in the implications of Religious
Court Class Iadecision of Bengkulu City Number: 0289/Pdt.G/2016/Pa.Bn?

B. RESEARCH

\section{METHODOLOGY}

The method used in this research by its nature is a qualitative research approach to empirical law. Qualitative research is research that takes a holistic approach, the approach that requires a variety of information to be analyzed, so as to understand certain aspects of human behavior. ${ }^{6}$ The research location is in Religion Court of Bengkulu. The data collection was done by in-depth study of documentation and interviews and analyzed using qualitative methods.

C. RESULTS

AND

\section{DISCUSSION}

Setting of Innate and Joint Assets Case of Divorce According to Law No. 11974 about Marriage in the

${ }^{6}$ Sirman Dahwal, Pelaksanaan Perkawinan Beda Agama (Studi Berbagai Kasus Di Indonesia Priode Tahun 19862010), Jurnal Ilmu Hukum Bengkoelen Justice,Program Pasca Sarjana Ilmu Hukum vol.2.No.2.2012,pg.464-465. 


\section{Implications of Religious Court Class IaDecision of Bengkulu City Number: 0289/Pdt.G/2016/Pa.Bn}

Treasure in marriage is distinguished on joint and innate assets or congenital origin. It is regulated in Article 35 of Law No. 1 of 1974 on Marriage, which is as follows:

(1). Asset acquired during the marriage become joint property;

(2).Innate Assets from each husband and wife and assets derived respectively as a gift or inheritance, is under the control of each parties as long as the parties do not agree otherwise.

Article 35 of Law No. 1 of 1974 on Marriage to explain the difference between innate and joint assets, where the innate asset is a property acquired before the marriage and property acquired by each of the spouses as a gift or inheritance, is under the control of their respective as long as the parties do not agree otherwise. Not otherwise specified in this case is not specified in a prenuptial agreement or other written agreement between both parties. Joint assets shared byHartanto, J. Andi is: ${ }^{7}$

"Assets earned by the couple together for the duration of the marriage bond. Joint assets and marital agreements often go unnoticed because people often think marriage is a sacred so it is unethical to talk about the problem of property or the division of joint assets during the marriage if there is ever a divorce."

Post-divorce issue concerning about joint assets often occur between ex-husband and ex-wife even the dispute over the joint property often involves the families of each party. Article 126 of the Civil Code regulates the things that make a joint asset is dissolved by law, they are:

Joint Asset is dissolved by law:

1. Because of death;

2. Because of marriage permission from the 2012, pg. 15. 
judge after a husband or wife does not exist:

3. Because of divorce;

4. Because of separate tables and beds;

5. Because of the separation of assets

Under Article 126 of the Civil Code, the divorce resulted the dissolution of joint asset, so it should be divided between husband and wife. Along with the sense of jointasset, the marriage as stipulated in Law No. 1 of 1974 and the Civil Code, Islamic Law Compilation also regulates the notion of joint assetas same as adopted in Law No. 1 of 1974 and the Civil Code above. Joint asset in Islamic Law Compilation is termed as "syirkah" which means wealth derived either alone or together with spouses during the marriage, regardless registered under any name. ${ }^{8}$

The setting of joint and innate asset is necessary, where the presence of the setting to

${ }^{8}$ Djais,

Mochammad,HukumHartaKekayaanD alamPerkawinan,

FakultasHukumUniversitasDiponegoro , Semarang, 2003, pg. 34 separation and distinction between the innate and joint asset will reflect and embody a legal certainty to both parties and will facilitate the judge in deciding the final case of divorce. The setting of joint and innate assetis contained in the Civil Code and Law No. 1 of 1974 about marriage and Islamic Law Compilation.

The legal basis of the joint asset can be traced through the laws and regulations as follows: 9

a. Marriage Law No. 1 of 1974 Article 35 verse (1), stated that the definition of joint asset is "Assets acquired during the marriage". It means, the property acquired before the marriage is not referred to joint asset

b. Book of Civil Law Article 119, states that "Since the time of holding the marriage, then according to the law, there is joint asset between husband and

\footnotetext{
${ }^{9}$ Happy Susanto, PembagianHartaGono-Gini SetelahTerjadinyaPerceraian, Alumni, Bandung, 2005,pg.59
} 
wife, to the extent of it is not held to other provisions in the agreement of marriage. Joint asset, as long as the marriage goes, can not be dismissed or amended by an agreement between the husband and wife "

c. Compilation of Islamic Law Article 85, states that "The existence of joint asset in marriage did not rule out their respective property of husband and wife". In this article mentioned that there is joint asset in marriage, but did not rule out their respective property of husband and wife.

As one of the basic laws on marriage and the legal basis of the innate and joint asset, Law No. 1 of 1974 about marriage set in the provision of some Articles as follow:

1. Article 35 verse (1) and (2) as follows:

(1). Asset acquired during the marriage becomesjointasset

(2). Asset inherited from each husband and wife and asset derived respectively as a gift or inheritance, is under the control of each partyas long as they do not agree otherwise.

2. Article 36 verse (1) and (2) as follows:

(1). Regarding jointasset, spouses can act on the agreement of both parties.

(2). Regarding the innate asset of each, spouses have the full right to take legal actions concerning assets.

3. Article 37 as follows:

"When the marriage broke up because of divorce, asset governed by the law of each."

The difference between joint and innate asset can be seen from the content of Article 35 verse (1) and (2) which states that:

1. Joint asset is asset acquired during the marriage;

It means that the asset is obtained and derived from the work of both husband and wife or together at the time of marriage.

2. Innate asset is the treasure of each husband and wife before the marriage and the 
asset derived from gifts and grants and heritage.

It means that the asset is obtained from the work and a gift of each partner where it is obtained before the wedding. Asset obtained from gifts, inheritance and grants even though it was given during the marriage to each party remains the innate asset of each party when it is not otherwise regulated. Another sentence that is not set here is to show that these provisions are not stipulated by other provisions in the laws, regulations or prenuptial agreement made by both parties.

According to the analysis of the author, ifArticle 35 verse (1) and (2) is analyzed using the theory of legal certainty, the Article constitutes legal security for individuals from government misappropriation because with the existence of general rules, individuals can know what may be charged or done by State against individuals. The security in question is each individual in this case the husband and wife can clearly find out which belong to the inheritance and joint assets through the arrangements contained in Article 35 verse (1) and (2) of Law No. 1 of 1974 concerning marriage. The regulation also aims to ensure that the judge does not decide on divorce related to disputedjoint and innate assets not arbitrarily and harming either party.

According to the analysis of the author, with the existence of legal certainty contained in Article 35 verse (1) and (2) of Law No. 1 of 1974 concerning marriage will reflect a fairness for each party, which according to JhonRawl the fairness of the procedure used to decide the outcome of distribution and how they apply. The procedural justice referred to if it is related to the provisions of Article 35 verse (1) and (2) of Law No. 1 of 1974 concerning marriage will make the judge as the case breaker refer to the Article and 
carry out the decision in accordance with a fair process. Procedural justice concerns the fairness and transparency of the process by which decisions are made, and can be compared with distributive justice (fairness in the distribution of rights or resources), and retributive justice (justice in wrongdoing). Hearing all parties before a decision is made is one of the steps that will be considered appropriate that must be taken so that the process can then be characterized as fair procedural.

Law No. 1 of 1974 concerning marriage also regulates the authority, rights and obligations of each party in the case of the possession of innate and joint assets regulated in Article 36 verse (1) and (2). The provisions of this Article state that for joint assets there are obligations and rights of each party, namely:

1. Mastery of joint assets can be controlled by both husband and wife;
2. Husband and wife can act on these joint assets on the agreement and agreement of both parties, the wife and husband;

3. Full rights to joint assets are the rights of both parties.

In addition to the elements contained in joint assets, the elements contained in the assets stipulated in Article 36 verse (2) of Law No. 1 of 1974 concerning marriage is as follows:

1. Assets belong to property owned by each husband and wife before marriage and after marriage but are obtained from inheritance, grants or gifts;

2. The right to inheritance is owned by each husband and wife;

3. Mastery of innate assets without the consent of both parties.

The elements contained in Article 36 verse (1) and (2) of Law No. 1 of 1974 concerning marriage is a form of implementation of the rule of 
law as expressed by Immanuel Kant stating that a country is called a rule of law if the country provides protection for individual human rights.

Protection of individual human rights can be seen from the regulation of the innate assets listed in Article 36 paragraph (2) of Law No. 1 of 1974 concerning marriage which guarantees and regulates the individual rights of each husband and wife as individuals who are free and have rights.

Separation of innate and joint assets regulated in laws and other regulations is a form of the role of government in realizing the values of the rule of law that accommodate all the interests and rights of each individual without too much interference from the government and in order to realize a process of justice based on the fairness of the law and provide certainty for every individual and interested parties in it.

According to the analysis of the author, the arrangement of the innate and joint assets in the case of divorce according to Law No. 1 of 1974 concerning Marriage has fulfilled the element of legal certainty and reflects the rule of law which provides protection and individual rights without interference and intervention from the government. Legal certainty and reflected the theory of State law in the regulation of innate and joint asset in the case of divorce according to Law No. 1 of 1974 concerning Marriage will facilitate the performance of judges in deciding cases of innate and joint assets that will open up great opportunities in realizing procedural justice and provide effectiveness to the role of judges in marriages and the distribution of innate and joint assets in divorce cases.

Decision of the Panel of Judges of the Religious Courts Class IA of Bengkulu City Number: 0289/Pdt.G/2016/Pa

a. In the convention:

1) To grant the Petitioner's petition; 
2) To establish a member of the permit for the Petitioner to drop the divorce of one Raj'I against the Respondent in front of the Bengkulu Religious Court session.

3) Order the Bengkulu Religious Court Registrar to send a copy of the pledge of pledges for the implementation of this ruling to the Marriage Registration Office of the Office of Religious Affairs in the City of Bengkulu Wide District and the Marriage Registration Office of the Office of Religious Affairs, Talo District, Selumagunda registered in the list provided for it;

b. In the reconciliation lawsuit:

1) To grant the claim of the Plaintiff in part;

2) Establishing custody rights / hadhonah rights of two children under hadhonah / custody of the Plaintiff (biological mother);

3) Punish Defendant to give to the Plaintiff in the form of:

a. Paying a living for 3 months $x \quad$ Rp. 500.000, - = Rp. 1.500.000, -

b. Mutation of entertainment for the wife) in the form of money in the amount of Rp. 500.000, -

c. Returning the innate asset (Honda motorcycle) for $\mathrm{Rp}$. 3.000 .000

d. Give a living to two children at least Rp. $1.000 .000, \quad-\mathrm{x} \quad 2$ children $=\mathrm{Rp}$. 2.000.000, - every month to the Plaintiff (biological mother) so that the adult child.

Based on the description above, then according to the analysis of the role of the judge 
in deciding the innate and joint assets in the case of divorce in the Religious Court Class IA of Bengkulu City Number: 0289/Pdt.G/2016/Pa.Bn if it is analyzed using the state law theory which is good according to Immanuel Kant stated that a country called a State Law if it provides protection for individual human rights. Protection of individual human rights according to the analysis of the author is reflected in the consideration of the panel of judges in the Religious Court Class IA decision of Bengkulu City Number: 0289/Pdt.G/2016/Pa.Bn, they are:

1. Point $\mathrm{j}$ in the convention claim stating: Considering because the Petitioners' petition is granted according to the provisions of Article 72 of Law Number 7 of 1989 amended by Act Number 3 of 2006 and Law Number 50 of 2009 the panel of judges ex officio needs to order the clerk of religious court of
Bengkulu to send a copy of the pledge of pledges.

Judge's consideration is a form of the implementation of the StateLaw which protects a person's human rights, where every person in the case of husband and wife has the right to file a divorce if he feels that the marriage relationship cannot be maintained and makes the individual feel depressed. Judges' considerations and decisions are also based on the rules of religious law and national law contained in the marriage law and $K H I$.

2. Point $\mathrm{c}$ up to point $\mathrm{g}$ in the consideration of the decision on the recovence lawsuit in which the judge guarantees the rights of individuals to be violated. Individual rights guaranteed include:

a. In point $\mathrm{c}$, the panel of judges Ex Officio punishes the applicant / defendant for the reconciliation who will divorce his wife must 
be fulfilled by the obligation of the husband who will divorce his wife with the provisions of Article 149 letters (a) and (b) and Article 152 and 158 letters (b) Compilation of Islamic Law. The panel of judges decides on the husband to give the wife's right, namely the living for three months in total ofRp. 1.500.000. - (one million five hundred thousand rupiahs) and land in the form of money in the amount of Rp. 500.000, - (five hundred thousand rupiah).

b. Point $d$ in the reconciliation suit which contains the provisions of the judge's consideration of custody of the two children, do not separate from father or mother, the panel of judges is of the opinion that according to the confession both parties have had two children stating their identity and are still underage, in accordance with Article 41 letters ( a), (b) and (c) of Act Number 1 of 1974, the purpose of which is due to a break up of marriage due to divorce; a. either mother or father is still obliged to maintain, educate his children solely based on the interests of the children. B. the father who is responsible for all the maintenance and education costs that the child needs, if the father does not fulfill the obligation, the court can determine that the mother will bear the cost; These considerations are a 
form of protection of

the basic rights of a child that is protected and cared for by the panel of judges in terms of staying alive and getting a decent life and education and love for both parents even though the parents have separated, but the children's rights remain protected in decisions that are not separated in divorce decisions.

c. Point $\mathrm{e}$ in the reconciliation suit which contains the provisions of the judge's consideration of the custody of the two children that the Plaintiff's child custody rights with the Defendant now join the Plaintiff as his biological mother because the child is underage in accordance with the provisions of Article 105 letters (a), (c) and Article 156 letters (a) and (e) compilation of Islamic law, namely in the event of a divorce (a). the maintenance of a child who has not been mumayyiz or is not 12 years old is the right of his mother. Then the second can be stipulated custody / hadhon's rights to the Plaintiff (biological mother). This decision is a form of protection provided by judges to children who are not old enough to be cared for by the mother with the considerations mentioned above.

d. Point $f$ in the reconciliation suit which contains the provisions of the judge's consideration of the child's right to receive treatment is a form of protection of 


$$
\begin{aligned}
& \text { the judges against } \\
& \text { individual rights and } \\
& \text { human rights of a child } \\
& \text { even if the child is } \\
& \text { born from a separate } \\
& \text { family but these rights } \\
& \text { must remain protected } \\
& \text { and contained in the } \\
& \text { divorce decision of } \\
& \text { both parents so that } \\
& \text { both parents can still } \\
& \text { undergo their } \\
& \text { obligations in } \\
& \text { protecting and giving } \\
& \text { away their children's } \\
& \text { rights. }
\end{aligned}
$$

The description above is in line with the legal state theory which was revealed by Julius Stahl where the concept of the state law or known as rechsstaat includes four important elements, and in the judgments and decisions the judges contain the four elements, namely: ${ }^{10}$

1. Protection of human rights.

The protection can be seen from the judge's decision on the individual's rights in the pg.27. case of the possessions owned by the wife before marriage that is used by the husband who must be returned after the divorce where the judge decides for the husband to return the inheritance (Honda motorcycle) for $\mathrm{Rp}$. 3.000.000. As well as children's rights to live and get a decent education where parents in this case are charged to provide a living for two children at least Rp. 1.000.000, $-\mathrm{x} 2$ children $=$ Rp. 2.000.000, - every month to the Plaintiff (biological mother) till they grow adult.

2. Distribution or separation of powers.

This is reflected in the government's decision to settle marriages in the institutions of the Religious Courts and Religious Court judges in every consideration of the judge, where in examining and deciding the judge is always in accordance with his 
authority and authority as regulated by law.

3. Government based on law.

This is reflected in every consideration of the Law which always refers to the Constitution and other regulating laws. This was also reflected in the judge's decision, which in every consideration and decision of the judge was guided by the marriage law and the Compilation of Islamic Law which regulated the divorce and distribution of inheritance and joint property.

4. Administrative court.

The administrative court is the State Administrative Court where in Indonesia the court is formed, so that the State Law element is fulfilled.

The role of the judge in deciding the innate and joint asset on the divorce case in the Religious Court Decision of Bengkulu City Number: 0289/Pdt.G/2016/Pa.Bn if reviewed by the effectiveness theory as expressed by Effendy which states that effectiveness is a communication which the process reaches the planned goals according to the budgeted costs, the time set and the number of personnel specified. The role of a religious court judge if viewed from the Religious Court Class IA decision of Bengkulu City No. 0289/Pdt.G/2016/Pa.Bn relating to innate and joint assets, the judge's decision has fulfilled the elements referred by Effendy regarding the effectiveness as follows:

1. Effectiveness is a communication. Thus according to the analysis of the author, the role of the judge related to the innate and joint assets in the decision Number: 0289/Pdt.G/2016/Pa.Bn has fulfilled the element of effectiveness, where the decision in the distribution of innate assets is communication from both parties based on the plaintiff's 
recognition and the

Defendant and for the assets not included in the decision constitute a communication between the judge, and the Plaintiff and the Defendant. Thus with this communication, the judge's decision was born as the role of the judge in deciding the marriage case in accordance with the Law and the rules governing it.

2. The planned destination element matches the budgeted costs. According to the analysis of the author, this element is reflected in the decision Number: 0289/Pdt.G/2016/Pa.Bn. With the judge's decision in the innate and joint assets to achieve a goal, namely to keep returning the wife's rights in the case of inherited assets in the form of Honda bike and the husband's garden before the wedding. As well as not deciding joint asset in the decision Number: 0289/Pdt.G/2016/Pa.Bnfor this reason it is not an initial goal of both parties to not be listed in the convention and reconciliation lawsuit.

Based on the description above, it can be concluded that the role of the judge in deciding the innate and joint assets contained in the decision Number: $\quad$ 0289/Pdt.G/2016/Pa has been effective where there is communication between the two parties and there are objectives achieved according with the communication of both parties.

The effectiveness of the role of the judge in deciding the innate and joint assets as stated in the decision Number: 0289/Pdt.G/2016/Paif viewed from the theory of effectiveness of Public Service Transformation according to AgungKurniawan, the role of the judge in deciding the innate and joint assets contained in the decision Number: 0289/Pdt.G/2016/Pa has reflected an effectiveness in carrying out tasks, functions (operations of program or 
mission activities) rather than an organization or the like that has no pressure or tension between its implementation.

\section{CLOSING}

\section{Conclusions}

Based on the results of the research and the descriptions that the author has described above, it can be concluded that the innate and joint assets in the case of divorce according to Law Number 1 of 1974 concerning Marriage has fulfilled the element of legal certainty and reflects the State Law that provides protection and individual rights without interference and intervention from the government. Legal certainty and the reflected theory of State Law in the regulation of innate and joint assets in the case of divorce according to Law No. 1 of 1974 concerning Marriage will facilitate the performance of judges in deciding cases of inheritance and joint assets that will open up great opportunities in realizing procedural justice and provide effectiveness to the role of judges in marriages and the distribution of innate and joint assets in divorce cases. In addition, the role of the judge in deciding the innate and joint assets on the divorce case in the Religious Court Decision of the City of Bengkulu Number: 0289/Pdt.G/2016/Pa.Bn in terms of the principle of justice in accordance with the existing mechanism and has reflected a the form of the role of the State as a State Law in creating a process and a protection for each individual.

\section{Suggestions}

Based on these conclusions, the suggestions submitted by the author are: The government should provide more common rules regarding the regulation of the innate and joint assets in the marriage law so that the 
role of judges is more effective and maximum.

\section{REFERENCES}

Djais, Mochammad, Hukum Harta Kekayaan Dalam Perkawinan, Fakultas Hukum Universitas Diponegoro, Semarang, 2003.

Happy Susanto, Pembagian Harta Gono-Gini Setelah Terjadinya Perceraian, Alumni, Bandung, 2005.

Hartanto, J. Andy, Hukum Harta Kekayaan Perkawinan, Cet.2, Laksbang Grafika, Yogyakarta, 2012.

Mohamad Ali Afif, LiliekIstiqomah, Moh. Ali, Eksekusi Putusan Pengadilan Agama Terhadap Harta Bersama Akibat Perceraian (Kajian Putusan Pengadilan Agama Pasuruan Nomor 1644/Pdt.G/2011/PA. Pas, E-Jurnal Fakultas Hukum, Universitas Jember(UNEJ),http://repository .unej.ac.id/bitstream/handle/12 3456789/58698/Mohamad\%20 Ali\%20Afif.pdf;sequence $=1$.

Mulyadi, HukumPerkawinan Indonesia, Badan Penerbit Universitas Diponegoro Semarang, 2008.

Sirman Dahwal, HukumPerkawinan Beda Agama DalamTeori Dan Praktiknya $D i$ Indonesia,MandarMaju, Bandung, 2016.

Sirman Dahwal, Pelaksanaan Perkawinan Beda Agama
(Studi Berbagai Kasus Di Indonesia Priode Tahun 19862010), Jurnal Ilmu Hukum Bengkoelen Justice,Program Pasca Sarjana Ilmu Hukum vol.2.No.2.2012.

Soemiyati, Hukum Perkawinan Islam dan Undang-undang Perkawinan Nomor 1 Tahun 1974, Liberty, Yogyakarta, 2004.

Syaik Muhammad Asy-Syarif, 40 Hadits Wanita, Hadits Fikih dan Akhlak ,Ummul Qura, 2013. 